УДК 332.01

(C) 2012

Воронько Т. В., кандидат економічних наук

Полтавська державна аграрна академія

\title{
СУТНІСТЬ І ГОЛОВНІ ЦЛІ РЕГІОНАЛЬНОГО МАРКЕТИНГУ ЯК СКЛАДОВОЇ РЕГІОНАЛЬНОЇ ПОЛІТИКИ
}

\section{Рецензент - доктор економічних наук, професор, илен-кореспондент НААН Украйни П. М. Макаренко}

Розглядаються сутність і головні иілі регіонального маркетингу та особливості його функиіонування за сучасних умов. Акцентовано увагу на обставинах, щуо стримують розвиток і функціонування маркетингу на всіх рівнях управління. Автор пропонує розширити існуючі нині иілі регіонального маркетингу. Зазначено, щьо, виступаючи частиною регіональної економічної політики, регіональний маркетинг відрізняється своєю направленістю на вирімення проблем регіону й включає розробку $i$ реалізацію концепції комплексного розвитку економіки й соиіальної сфери території, спрямовану на вирішення ії соціально-економічних проблем.

Ключові слова: регіон, територія, маркетинг, регіональний маркетинг, макрорівень, мезорівень, мікрорівень.

Постановка проблеми. За умов здійснення регіональної реформи в Україні регіони отримують більшу самостійність, можливість проведення відповідної соціально-економічної політики, відповідальність за прийняття та здійснення управлінських рішень (основа яких грунтується на специфіці окремої територіi), виявлення ii пріоритетних напрямів, а також ефективного узгодження інтересів на макро- (держава), мезо(регіон) та мікрорівнях (окремі суб'єкти господарювання). Тому доцільно розглядати етапи формування й розвитку регіонального маркетингу у поєднанні ринкових і державних механізмів регулювання.

Розвиток країни може стримувати неоднорідність регіонів, а саме: різниця в їх господарському розвитку, існуючий рівень співпраці між ними, система цінностей населення тощо. Саме тому держава повинна мати чітку стратегію регіонального розвиту країни в цілому, що знаходитиме своє відображення в ефективній регіональній політиці.

Президент України підкреслює, що «...3 2012 роком зміст нової регіональної політики полягає у наданні регіональним органам влади власної можливості для реалізації регіональних потенціалів, i, в першу чергу, на принципах залучення регіоном вітчизняних та іноземних інвесторів, створення у регіонах сприятливого інвестиційного клімату, відкритості та професіоналізму інвестиційних пропозицій, здатності працювати 3 інвесторами в оперативному, діловому і відкритому стилі» [8].

Водночас зауважимо, що впровадження маркетингу на всіх рівнях управління стримує низка обставин, головними з-поміж як $є$ :

- недостатній рівень запровадження існуючих прогресивних досягнень маркетингу;

- нестабільна ринкова ситуація, що зумовлена змінами в законодавстві, низькою конкурентоспроможністю національних товаровиробників, відсутністю ефективних зв'язків між окремими галузями й високим рівнем монополізму в деяких із них, незадовільним рівнем купівельної спроможності та інвестиційної привабливості окремих територій. Актуальність теми даного дослідження обумовлена передусім необхідністю удосконалення управління соціальноекономічним розвитком регіону.

Аналіз останніх досліджень і публікацій, у яких започатковано розв'язання проблеми. Питання розвитку регіонів і маркетингу знайшли своє відображення у працях передусім зарубіжних вчених: В. Абрамова, I. Арженівського [1], А. Гапоненко [2], В. Захарова, А. Куренкової, А. Лаврова [5], С. Мельникова, А. Панкрухіна [6], Є. Попова, Г. Почепцова, Р. Фатхутдинова, А. Дайан, Ф. Котлера та інших. Проблема формування маркетингової стратегії розвитку регіонів в умовах посилення інтеграційних процесів неодноразово висвітлювалася в наукових працях українських вчених-економістів: О. Мельничука, Л. Балабанової, Ю. Шарова, О. Крайника та інших. Однак, дані фахівці розглядають лише окремі аспекти розвитку, функціонування маркетингу на певному рівні управління чи обгрунтування взаємовигідних відносин регіонів із центром. Різні аспекти проблеми узгодження взаємозв'язків між регіонами та особливості створення ефективного регіонального маркетин- 
гу - як складової регіональної політики - за сучасних умов потребують більш грунтовного вивчення.

Метою статті $є$ доведення необхідності впровадження регіонального маркетингу у контексті регіональної політики на даному етапі здійснення реформ.

Результати дослідження. За сучасних умов держава (центр) допоки що не має достатньої кількості ресурсів для забезпечення високого якості життя населення, незалежно від регіону, тому значні очікування покладаються на регіональні та місцеві органи влади, зокрема на їх якість роботи, створення робочих місць, здатність залучення інвестицій, приваблення потенційних споживачів тощо.

«Важливим засобом регіональної політики у країнах, які мають значний досвід у цій сфері (Японія, Франція, Італія та ін.), є регіональний маркетинг. Регіони у даному випадку можливо розглядати як певні корпорації, що конкурують за ресурси та споживачів. Відповідно, можна говорити про необхідність розробки конкурентної політики регіонів, політики ринкової діяльності. Таким чином, мова йде про маркетинг регіону як складової частини регіональної політики. Маркетинг регіону у відповідності з сучасними підходами можна визначити як спосіб встановлення, створення, підтримки таких відносин із різними суб'єктами ринку, які б забезпечували вигідні позиції регіону у відношенні до ресурсів і цільових ринків, а також дозволяли досягати задоволення цілей учасників відносин. Таким чином, маркетинг регіону направлений на виявлення потреб контрагентів регіону, узгодження цих інтересів 3 його інтересами та досягнення на цій основі конкурентного успіху та соціально-економічних цілей» [7].

Економічна енциклопедія за редакцією С. В. Мочерного трактує поняття «регіон» як комплекс підсистем, елементів та компонентів і їх характерних властивостей, взаємодія між якими та середовищем зумовлює якісно або сутнісно нову інтегративну цілісність [3, с. 58-59].

Регіональний маркетинг, на думку А. Лаврова та В. Сурніна, є елементом ринкової системи, що сфокусований на мезорівень і не передбачає вивчення попиту, цін на продукцію окремого підприємства, а мова вже йде про вивчення ринку, попиту і цін на сукупну продукцію регіону, реалізацію всього його потенціалу. Регіональний маркетинг трактується ними як система економічних відносин узгодження економічних інтересів і цілей мезорівня з макро- і мікрорівнями, адаптації регіональної структури відтворення до зовнішнього та внутрішнього ринків на основі постійного моніторингу (аналіз, оцінка та прогноз) процесів, що відбуваються на них [5, с. 4547]. Варто зауважити, що дані дослідники основну увагу зосередили на внутрішньому середовищі регіонального маркетингу, залишивши поза увагою вплив зовнішнього.

Водночас А. Гапоненко, розглядаючи інструментарій управління економічним розвитком регіону та комплекс заходів, спрямованих на залучення на територію бажаних економічних суб'єктів, визначає регіональний маркетинг як систему, що складається з маркетингу землі, житла, зон господарської забудови, інвестицій, туристичного маркетингу, виділяючи окремою його метою донесення до цільових споживачів інформації про регіон як місце для ведення бізнесу [2, c. 43-45].

Котлер Ф. дане явище об'єднує поняттям «маркетинг місць», тобто маркетинг землі та інвестицій інтегруються ним у поняття «маркетингу інвестицій у земельну власність», а туристичний маркетинг відображається поняттям «маркетинг місць відпочинку». За його словами, маркетинг місць - це діяльність, що здійснюється 3 метою створення, підтримки чи зміни відносин і поведінки щодо конкретних місць [4, с. 69-70].

У своїх наукових дослідженнях А. Панкрухін чітко розмежовує територіальний маркетинг на маркетинг, що реалізується в межах даної територіï, і маркетинг, зорієнтований на суб'єктів за iii межами. Маркетинг території розглядається ним як «...діяльність, що здійснюється 3 метою створення, підтримки чи зміни відносин і поведінки суб'єктів ринку, соціальних спільнот щодо конкретних зосереджених там природних, матеріально-технічних, фінансових, трудових і соціальних ресурсів, а також можливостей їхньої реалізації та відтворення» [6, с. 34-40]. Логічно розділяючи зміст територіального маркетингу 3 урахуванням потреб i можливостей цільових споживачів, автор демонструє фаховий підхід щодо висвітлення напрямів використання інструментарію для забезпечення ефективного розвитку території. Все вищесказане можна повною мірою віднести до регіонального маркетингу, поскільки в економіці регіону розглядаються переважно територіальні системи мезорівня - область, економічний район, республіка.

Як справедливо зазначив I. В. Арженовський, правильніше було б розуміти регіональний маркетинг як «...передову ідею, філософію, що вимагає орієнтації на потреби цільових груп спо- 
живачів послуг території. Не один відділ адміністрації чи спеціальне підприємство, а всі, що відповідають за долю регіону, повинні орієнтуватися на потреби клієнтів і цільові групи, а також на створення кращих, у порівнянні з іншими територіями, конкурентних переваг на користь клієнтів» [1, с. 124-125].

Розділяємо думку дослідників, які розмежовують такі поняття як «маркетинг у регіоні» та «регіональний маркетинг». Маркетинг у регіоні, стверджують вони - це комплекс заходів стандартного маркетингу щодо конкретних товарів i послуг у межах певного регіону, що характеризується специфічними особливостями маркетингового середовища. Регіональний маркетинг, у свою чергу, на відміну від підходів, що розділяють його на внутрішній і зовнішній, розглядається як інтегральна діяльність у регіоні та за його межами стосовно зосереджених у ньому ресурсів і можливостей їх реалізації та відтворення.

Основною задачею регіонального маркетингу $\epsilon$ створення нових і зміцнення існуючих переваг для залучення у регіон економічних агентів, здатних підвищити добробут жителів регіону. Серед цілей такого маркетингу науковці зазначають наступні:

1. Зростання ступеня ідентифікації громадян із територією проживання.
2. Забезпечення відомості про певну територію вище регіонального (національного).

3. Ріст зайнятості, доходів населення та якості життя, формування сприятливої демографічної структури, сприяння соціальному і культурному прогресу, збереження природного середовища та покращання екологічної ситуації.

4. Сприятлива для регіону реалізація ресурсного потенціалу.

5. Зростання конкурентоспроможності підприємств регіону.

6. Залучення у регіон нових підприємств та інвесторів з інших регіонів (країн).

7. Створення сприятливих умов для розвитку малого і середнього бізнесу.

8. Залучення до регіону нових споживачів товарів і послуг, що виробляються (надаються) регіоном.

9. Створення позитивного ділового іміджу регіону в країні та за кордоном.

10. Реалізація внутрішнього маркетингу, спрямованого на створення корпоративної культури регіону, системи цінностей та самоідентифікації території, іiі населення й суб'єктів господарювання, розвиток соціального капіталу регіону $[1$, c. $125 ; 7]$.

Пропонуємо доповнити цілі регіонального маркетингу наступними (див. рис.).

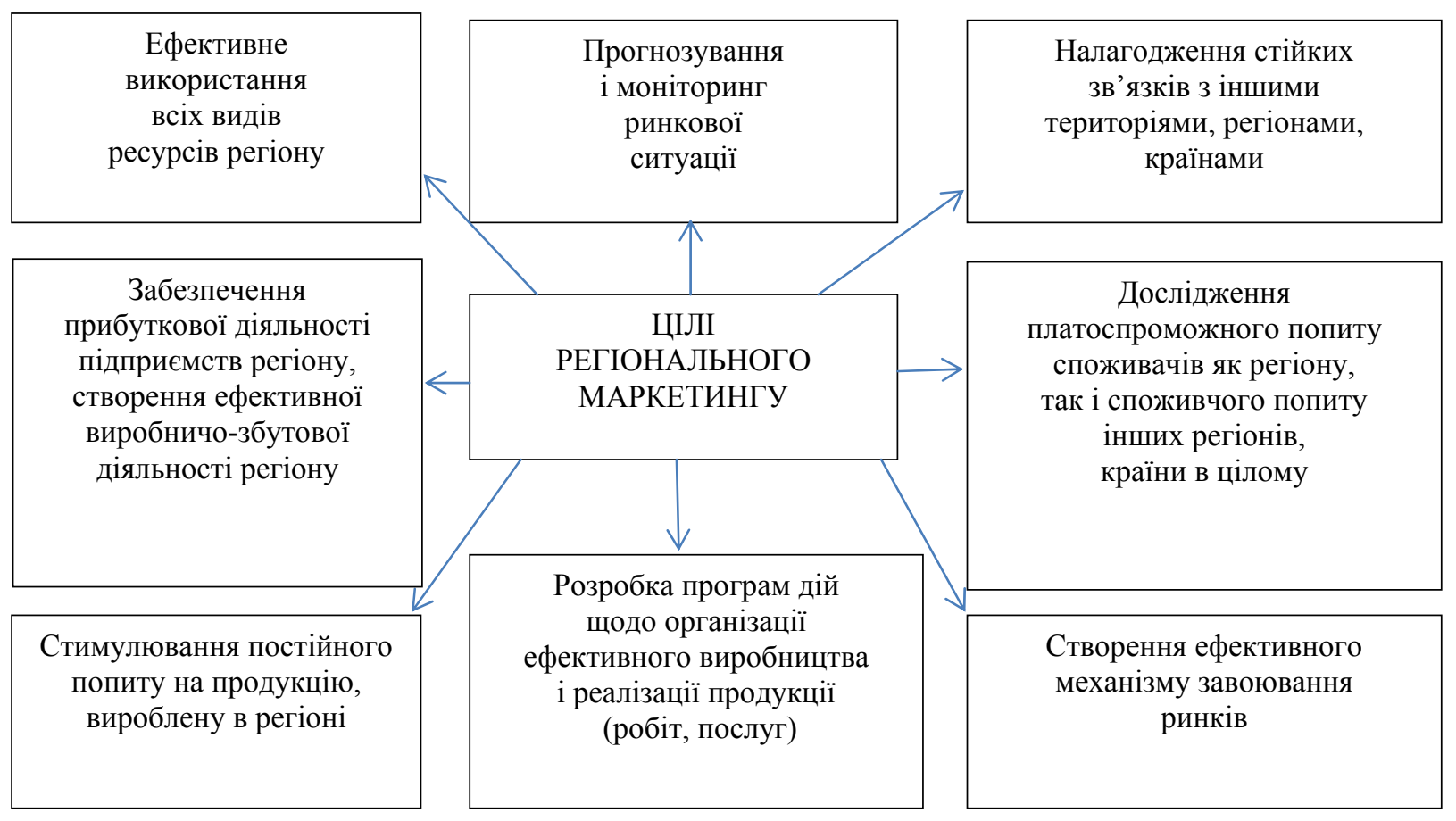

Рис. Цілі регіонального маркетингу 
Серед запропонованих нами цілей виділено прогнозування і моніторинг ринкової ситуації; налагодження стійких довгострокових зв'язків 3 іншими територіями, регіонами, країнами; дослідження платоспроможного попиту споживачів як регіону, так і споживчого попиту інших регіонів, країни в цілому; створення ефективного механізму завоювання ринків; розробка програм дій щодо організації ефективного виробництва i реалізації продукції (робіт, послуг); стимулювання постійного попиту на продукцію, вироблену в регіоні; забезпечення прибуткової діяльності підприємств, створення ефективної виробничо-збутової діяльності; ефективне використання всіх видів ресурсів (ресурсний потенціал) регіону тощо.

Для ефективного управління регіональним маркетингом, виконання його основних завдань i досягнення визначених цілей варто, на нашу думку, створити регіональний маркетинговий центр у формі так званого некомерційного партнерства. До його складу могли б входити, окрім представників регіональної влади, власники провідних підприємств, від успішної діяльності яких залежить розвиток, функціонування та імідж регіону; представники засобів масової інформації та рекламних, PR-, Event-агентств тощо. За досвідом функціонування таких організацій регіонального розвитку доцільно звернутися до східноєвропейських країн. Такі організації $\epsilon$ неурядовими, а кошти на функціонування виділяються на конкурсній основі, що сприяє стимулюванню ініціатив «знизу». 3-поміж функцій даного центру слід виділити наступні:

1) виявлення сприятливих чинників розвитку регіону та розробка ефективного механізму нівелювання несприятливих;

2) створення й реалізація стратегій розвитку ре-

\section{БІБЛІОГРАФІЯ}

1. Арженовський I. В. Маркетинг регіонів / I. В. Арженовський // Економіка та держава. 2007. - № 3. - C. 124-127.

2. Гапоненко A. Л. Управління економічним розвитком на регіональному рівні / А. Л. Гапоненко // Економіка України. - 2006. - № 3. - С. 43-52.

3. Економічна енциклопедія : У 3 т. / Редкол. : С. В. Мочерний (відп. ред.) та ін. - К. : Видавничий центр «Академія», 2002. - Т. 3. - 361 с.

4. Котлер Ф. Основы маркетинга / Ф. Котлер. М. : Вильямс, 2001. -388 с.

5. Лавров А. М. Реформування економіки: регіональні аспекти / А. М. Лавров, В. С. Сурнін // Економіка України. - 2006. - № 8. - С. 45-51. гіону як складової частини регіональної політики;

3) генерування заходів стосовно покращання іміджу регіону на національному та міждержавному рівнях;

4) підготовка плану дій зі структурної перебудови території, що створюють сприятливі умови для підприємницької діяльності;

5) розробка пропозицій відносно зростання інвестиційної привабливості регіону, аналіз та оцінка бізнес-проектів тощо.

Висновки. Існуючі державні механізми управління регіоном ще не повністю відповідають задачам i цілям. Управління соціальноекономічним розвитком регіону вимагає нових підходів і методів, враховуючи його особливості. За сучасних умов регіональний маркетинг $є$ тим інструментом, який дає змогу забезпечити стійкий взаємозв'язок між регіонами України. Будучи складовою частиною регіональної економічної політики, регіональний маркетинг відрізняється від традиційного своєю спрямованістю на вирішення проблем регіону та його територіальних утворень. Він включає розробку і реалізацію концепції комплексного розвитку економіки й соціальної сфери території, спрямовану на вирішення іiі соціально-економічних проблем.

Дослідження стану регіонального маркетингу свідчить про те, що чим глибше здійснюється вивчення й оцінка власних потреб, платоспроможного попиту, стану ринку в регіоні, тим позитивнішим i ефективнішим буде вплив на оптимізацію структури виробництва й обсягу споживання. Забезпечення зайнятості населення регіону, створення нових робочих місць, контроль за рівнем безробіття, формування системи соціального захисту сприяє перерозподілу працівників у пріоритетні галузі господарств регіону, створенню додаткових робочих місць тощо.

6. Панкрухін А. П. Маркетинг територій : [навч. посіб. для студ. вищ. навч. закл.] / А. П. Панкрухін. - К. : Знання, КОО, 2003. - 203 с.

7. Региональный маркетинг (маркетинговые методы в региональной политике). - Электронный pecypc. - Режим доступа // http:/www.bcimarketing.aha.ru/content/regionalnyi-marketingmarketingovye-metody-v-regionalnoi-politike.

8. Янукович B. Ф. Региональная политика в Украине с 2012 г. будет осуществляться через призму экономических реформ. - Электронный pecypc. - Режим доступа // http://www.rbc.ua/rus/ newsline/show/yanukovich-regionalnaya-politika-vukraine-s-2012-g-budet-09122011113500. 